\title{
Composition, structure and diversity of tree species along an elevational gradient in Dudu forest range, Jammu and Kashmir, India
}

\author{
Pinki Manhas \\ GGM Science College, Canal Road, Jammu (J\&K), India \\ Anil K. Raina* \\ Department of Environmental Sciences, University of Jammu, Jammu (J\&K), India \\ *Corresponding author. E-mail:anilkraina@yahoo.com
}

\section{Article Info}

DOI:10.31018/jans.v10i3.1847

Received: July 24, 2018

Revised: August 4, 2018

Accepted: August 10, 2018

\section{How to Cite}

Manhas, P. and Raina A.K. (2018). Composition, structure and diversity of tree species along an elevational gradient in Dudu forest range, Jammu and Kashmir, India. Journal of Applied and Natural Science, 10(3): 981 - 985

Keywords: Altitudinal gradient, Community structure, Diversity indices, Dudu forest range, Tree species

\section{INTRODUCTION}

Mountains are of great significance owing to the fact that they support very diverse ecological communities, including many endemic species (Korner, 2003) and have great value for historic, aesthetic and economic reasons. In mountain areas, the vegetation is greatly affected by differences in the microclimate, aspect and altitude (Pande et al.,2002; Chaudhary, 1999). The natural forest stand of any place is the result of the interaction of various environmental factors. The physiographic features such as elevation and aspect have a profound influence on the distribution, growth, form and structure of tree species, as a result of which the individual tree species has different values for density and basal area at various altitudes and aspects (Wikum and Wali, 1974). The factors such as soil nutrient content, slope, aspect and altitude have been shown to exert an important control on species richness and diversity on a great variety of ecosystems (Brocque and Buckney, 2003).

Altitude itself represents a complex combination of related climatic variables closely correlated with numerous other environmental properties (Ramsay and Oxley, 1997). The type of tree group at any place might also be due to the properties of vegetation itself in accordance with the climatic zones in which particular classes of vegetation are expected to flourish or due to the properties of a mature ecosystem comprising the vegetationenvironment complex, reflecting the interrelation of these elements (Gairola et al., 2011). Several studies, especially focusing on the species composition along elevational gradients, have been conducted and described by Saxena et al. (1985);Adhikari et al. (1992); Austin et al.(1996); Brun et al.(2006); Sharma et al. (2009); Majila and Kala (2010); Mark (2012); Rezende et al.(2015); Song et al.(2016); Sharma et al. (2017); and Sinha et al. (2018) who have reported that vegetation types differ with change in altitude. In Jammu and Kashmir also, some studies have been carried out to describe the variation in vegetation along altitudinal gradient. These include the works of Jhangir (2004), Raina and Sharma (2012); Arshad et al. (2013); Sharma and Raina (2013); Sharma et al. (2016). However, no such studies have been reported so far from the Dudu forest range of Jammu \& Kashmir (J\&K), India where the present work has been undertaken with the objective to describe and examine the structure and composition of the tree vegetation along an altitudinal gradient.

\section{MATERIALS AND METHODS}

Study area: The present study has been carried out in Dudu forest Range of Udhampur Forest Division $\left(33^{\circ} 10^{\prime}\right.$ North latitude and $75^{\circ} 35^{\prime}$ East longitude) of J\&K state, India. Data has been col- 
Manhas, P. and Raina, A.K. / J. Appl. \& Nat. Sci. 10 (3): 981 - 985 (2018)

lected along the altitudinal gradient ranging from 950 to $3500 \mathrm{~m}$ a.s.I. in which vegetation strata varies from subtropical forest to temperate forest (Fig.1). The area lies adjacent to the Shivaliks range and is highly mountainous region marked with rugged topography. Snowfall is a regular feature at higher elevations during winter whereas summer is moderate and pleasant.

Sampling and data analysis: The general survey of the study area has been carried out to determine the nature of terrain, tree composition, distribution and accessibility of different forest types of the study area. After the reconnaissance survey, different forest types according to altitude, aspect and species compositions were selected for the study and named according to the composition of dominant tree species as per Prakash (1986), Gairola et al.(2011) and Sharma and Raina (2013), viz., > $75 \%$ as pure; $50-75 \%$ as mainly; $25-50 \%$ as mixed and $<25 \%$ as miscellaneous. Physiographic factors i.e. altitude and aspect across different forest types were measured by GPS (Garmin-GPS map 60CSx). For the collection of primary data, 15 quadrats of $10 \times 10 \mathrm{~m}^{2}$ size each were laid out in each forest type for quantitative analysis of the tree vegetation (Curtis and Mclntosh, 1950). Species richness (SR) was simply taken as a count of total number of species in that particular forest type.

Margalef index (Margalef, 1958) and Menhinik index (Whittaker, 1977) has been calculated to work out the species richness (number of species per unit area) by using the following formulas:

Margalef index: $\mathrm{SR}=(\mathrm{S}-1 / \ln \mathrm{N})$

Menhinik index: $S / \sqrt{ } N$, where, $S=$ number of species and $\mathrm{N}=$ total number of individuals of all the species

The diversity $\left(H^{\prime}\right)$ has been determined by using Shannon-Wiener diversity index $\left(\mathrm{H}^{\prime}=-\Sigma p \mathrm{i}\right.$ In $\left.\mathrm{pi}\right)$ (Shannon and Weaver 1963) while the Simpson concentration of dominance has been calculated for each forest type by using the relationship $\left.D S=\sum n(n-1) / N(N-1)\right)$, (Simpson, 1949).

\section{RESULTS AND DISCUSSION}

Community structure and composition: The present study revealed the presence of 10 different types of the forests along the altitudinal gradients (950 $\mathrm{m}$ to $3500 \mathrm{~m}$ a.s.I.) of the study area (Table 1). The lower altitudes (950-1300 m a.s.l.) exhibited the prevalence of subtropical tree species with marked predominance of Chir pine community having Pinus roxburghii as dominant species along with Robinia pseudoacacia, Dalbergia sissoo, Ficus palmata, Ailanthus excelsa, Pyrus pashia, Alnus nitida, Olea ferruginea etc.

The mid altitudinal ranges in the present study area exhibited the dominance of temperate coniferous species. In the middle portion of the slope (1400-2100 ma.s.I.), the increase in elevation re-

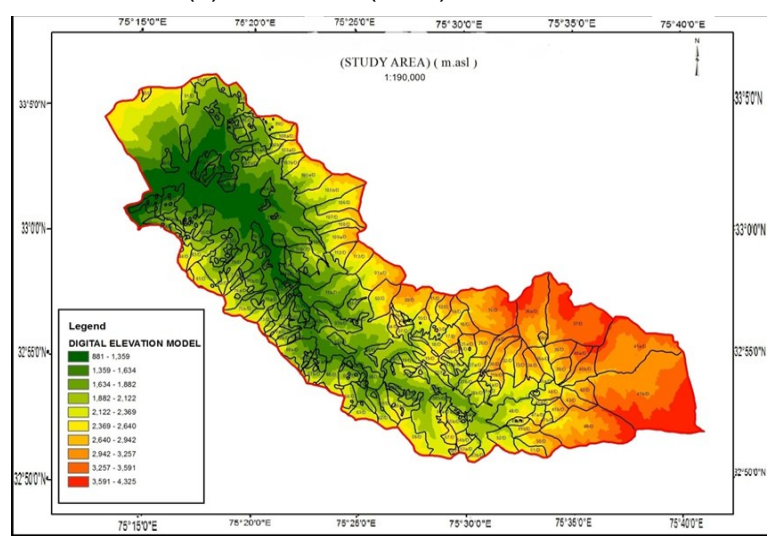

Fig.1. Digital elevation map of Dudu Forest range of Udhampur Forest Division, Jammu and Kashmir state. (Source- ICT PI Division Jammu, J\&K).

sults in change of dominance of species from $P$. wallichiana to Cedrus deodara. $P$. wallichiana in this portion is having the association with the broad leaved species like Quercus leucotrichophora, A. nitida, Juglans regia, Morus alba etc. C. deodara starts its appearance at elevation of about $1700 \mathrm{~m}$ and dominates the area above 1800 $\mathrm{m}$ up to $2900 \mathrm{~m}$ a.s.l. However, in some areas of the study it also occurs as co-dominant species with P. wallichiana (2100-2500m a.s.I) and Abies pindrow (2500-2900 $\mathrm{m}$ a.s.I.).

In the upper portion of the region, having steep to very steep slopes, coniferous species like $C$. deodara, A. pindrow, Picea smithiana exhibited their predominance. The broad leaved trees inter spreading in $C$. deodara in this portion includes, $A$. excelsa, Aesculus indica, A. nitida, J. regia, whereas in $A$. pindrow forest the broad leaved associates includes Rhododenderon arboreum, $A$. indica, Quercus semicarpifolia, Betula utilis etc. However, at tree line, broad leaved species of $B$. utilis predominates the area and is associated with few individuals of $A$. pindrow, $P$. smithiana, $R$. arboretum which are, however, of small sizes.

Species richness and diversity parameters: The various diversity indices calculated for the different tree species along the altitudinal gradient (950 $\mathrm{m}$ to $3500 \mathrm{~m}$ a.s.l.) has been depicted in Table 2.

Species richness: The mid altitudinal ranges have been reported to have higher species richness which decreases towards upper as well as lower altitudes (Chawla et al., 2008, Arshad et al., 2013). In the present study also, overall species richness has been recorded higher in the middle ranges (1600-2500 $\mathrm{m}$ a.s.l.) of the gradient as compared to lower and as well higher elevation ranges (Table 2). However lower altitudinal range having Subtropical Pine Forest (13), Subtropical scrub (10) and Pinus /Oak mixed forest (7) have higher diversity in comparison to higher altitudinal range $B$. utilis/ Fir forest (3), Deodar / Silver fir 
Table 1. Environmental variables across different altitudes of Udhampur Forest Division, Jammu and Kashmir State.

\begin{tabular}{|c|c|c|c|c|c|c|}
\hline S.N. & Forest type & $\begin{array}{l}\text { Altitude (in } \mathrm{m} \\
\text { above sea level) }\end{array}$ & Climate & Aspect & $\begin{array}{l}\text { Nature of } \\
\text { Slope }\end{array}$ & $\begin{array}{l}\text { Posi- } \\
\text { tion }\end{array}$ \\
\hline 1. & Betula utilis /Fir forest & $3100-3500$ & & Northeast & Steep & Upper \\
\hline 2. & Fir / Spruce mixed forest & $2900-3300$ & & Northeast & Very steep & Upper \\
\hline 3. & Deodar /Blue pine mixed forest & $2500-2900$ & & North west & Steep & Upper \\
\hline 4. & Deodar Pine mixed forest & $2100-2500$ & T & South east & Steep & Upper \\
\hline 5. & Mainly Cedrus deodara forest & $1800-2300$ & Temperate & South east & Steep & Upper \\
\hline 6. & Deodar/ Oak mixed forest & $1700-2100$ & & North west & Moderate & Middle \\
\hline 7. & Pinus roxburghii /Oak mixed forest & $1600-1900$ & & Northeast & Steep & Middle \\
\hline 8. & Pinus wallichiana / Alnus mix forest & $1400-1900$ & & South east & Moderate & Middle \\
\hline 9. & Subtropical Pine Forest & $950-1300 m$ & & South west & Moderate & Lower \\
\hline 10. & Subtropical scrub & $950-1100$ & Subtropical & South & Moderate & Lower \\
\hline
\end{tabular}

Table 2. Diversity parameters of tree species along altitudinal gradient of Udhampur Forest Division, Jammu and Kashmir State.

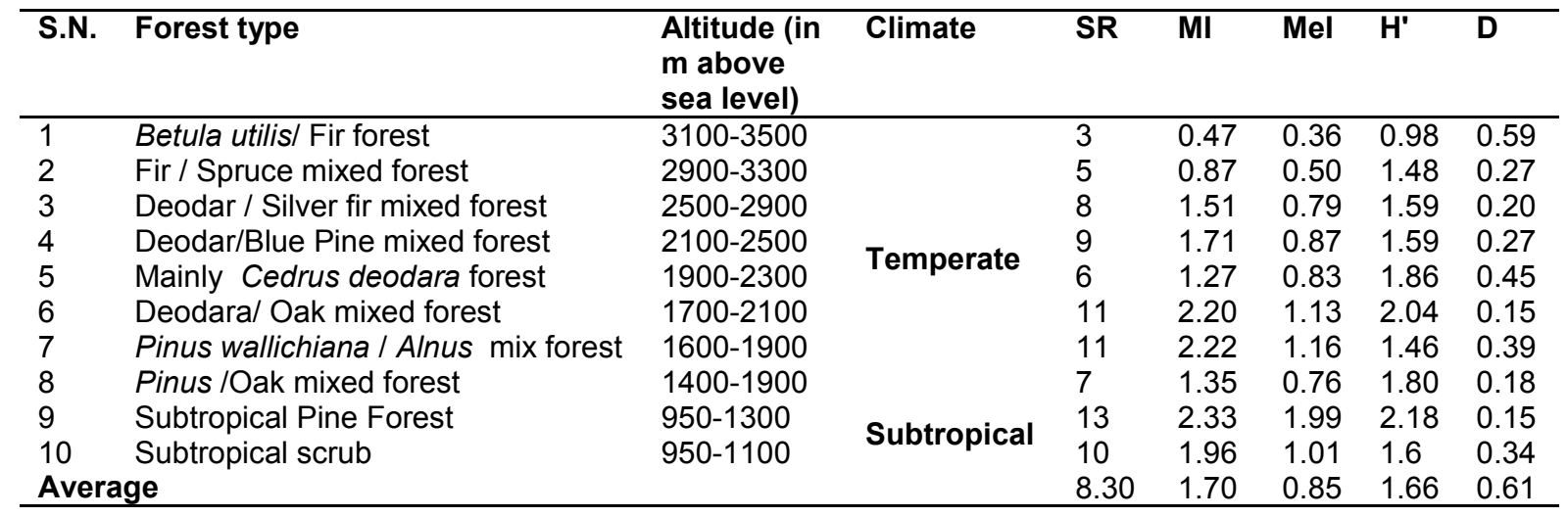

Where, MI: Margalef's Index; Mel: Menhinik Index ; H': Shannon-Weiner Index and D: Simpson Index.

mixed forest (5) and Fir / Spruce mixed forest(8). Mid altitudinal range having $P$. wallichiana / Alnus mix forest(11), Deodar/ Oak mixed forest (11), mainly $C$. deodara forest(6) and Deodar/Blue Pine mixed forest(9) have the maximum species richness(SR). Singh et al. (2006) also found maximum species richness at intermediate elevations. The value of the SR has been reported to decreases with the increase in the altitudes (Sinha et al., 2018; Raina and Sharma, 2012) which have also been recorded in the present study.

The Species richness indices, Menhinik Index (Mel) and Margalef's Index (MI), also exhibited the same trend in their values (Table 2) and have the maximum values in the mid altitudinal ranges having $P$. wallichiana / Alnus mix forest; Deodara/ Oak mixed forest; mainly $C$. deodara forest and Deodar/Blue Pine mixed forest. However, towards lower as well as towards upper portion of the slope, the value of Mel and Ml decreases. The values of these indices were more or less similar to the values reported for other regions of Himalayas (Gairola et al., 2011, Sharma and Raina, 2013, Pala et al., 2016, Geelani et al., 2018).

The higher diversity of plants in the middle portion of these ranges can be attributed to the merging of species from lower as well as upper portion of the ranges and also occurrence of some characteristic species of this elevation only. Also, higher diversity of species at lower as well as mid altitudi- nal ranges can be attributed to human interference in these areas which facilitates the introduction of non-native species as has also been reported by Rawat and Pangtay (1994).

The Shannon-Weiner diversity Index (H') Index for Indian forests has been found to range between 0.83-4.1 (Visalakshi, 1995), the value of which generally ranges from 1.5 to 3.5 . In Himalayan forests, its value has been reported to vary from 0.4 to $2.8,0.08$ to 1.29 , and 1.55 to 1.97 by Singh et al. (1994), Shivnath et al. (1993) and Mishra et al.( 2000),respectively. During the present investigation its value ranges from 0.47 to 2.33 in different types forests.

The value of Simpson index decreases with increasing diversity (Simpson, 1949). In the present study the values of Simpson index ranges from 0.15 to 0.59 and decreased with increasing diversity i.e. highest in Betula/ Fir forest (0.59) and lowest if Subtropical pine forest $(0.15)$. The values of Simpson index were more or less similar to the earlier reported values for the temperate forests such as 0.33-.46 in Western Himalayas (Gairola et al., 2011); 0.31-.42 in Gharwal Himalayas (Mishra et al., 2000) and 0.19-0.99 for temperate vegetation (Whittaker, 1965). The lower diversity and consequently greater Simpson value in the temperate vegetation could be due to lower rate of evolution and diversification of communities and severity of environment (Sharma et al., 2009; Simpson, 
1964)

On comparing the average values of diversity indices (Table 2), it was found that the overall values of Shannon-Weiner Index (1.66), Margalef's Index (1.70), Menhinik Index (0 .85) were lower than temperate forests of Kishtwar $(2.78,2.95,0.37)$ as reported by Kumar (2012), and higher than the values of temperate forests of Chattargalla Ridge, Bhaderwah $(1.20,0.89,0.36)$ as reported by Sharma et al.(2016).

The present data recorded to understand the composition, structure and diversity of tree species along an altitudinal gradient also find support from the studies carried out by various ecologists for the different temperate forests of Himalayan region (Rawat, 2001; Pande et al.,2002; Singh and Koushal, 2006, Gairola et al., 2011 and Sharma and Raina, 2013).

\section{Conclusion}

The present study revealed the poor status of species richness varying from 3 to 9 at higher altitudes of temperate forests while higher species richness ranging from 7 to 11 has been recorded in the middle portion of the elevation gradients. Menhinik Index (Mel), Margalef's Index (MI) and Shannon-Weiner diversity Index ( $\left.H^{\prime}\right)$, more or less, also have same trend while the values of Simpson index decreases with increasing diversity. Thus, cold and higher elevational portion of the regions which have the least diversity, require priorities for constant monitoring and conservation. The study also suggests that the species richness and distribution of different types of forest vegetation are largely regulated by varying climatic and physiognomic condition.

\section{REFERENCES}

1. Adhikari, B.S., Joshi, M., Rikhari, H.C. and Rawat, Y.S. (1992). Cluster Analysis (Dendrogram) of high altitude $(2150-2500 \mathrm{~m})$ forest vegetation around Pindari glacier in Kumaun Himalaya, Journal of Environmental Biology, 13:101-105.

2. Arshad, M.,Choudhary, S.K., Manzoor, K.Fatima,S., Mustafa, G.,Malik, N.Z. and Akrim, F. (2013).Altitudinal variation in plant species diversity and its components at kotli hills, Azad Kashmir. Archives Des Sciences,66(5):614-621.

3. Austin, M.P., Pausas, J.G. and Nicholas, A.O. (1996). Patterns of species richness in relation to environment in south eastern New South Wales, Australia. Australian Journal of Ecology, 21:154-164

4. Brocque, A.F. and Buckney, R.T. (2003). Species richness-environment relationships within Coastal sclerophyll and mesophyll vegetation in Ku-ring-gai Chase National Park, New South Wales, Australia. Austral Ecol. 28:404-412.

5. Brun, M.A., H.H., Moen, J., Virtanen, R., Grytnes, J.A., Oksanen, L. and Angerbjorn, A. (2006).Effects of altitude and topography on species richness of vascular plants, bryophytes and lichens in alpine communities. Journal of Vegetation Science, 17:3746.
6. Chaudhary, R.P.(1999). Vegetation Pattern. In:T. C. Majpuria (ed). Nepalnature'sparadise,105- 111.

7. Chawla, A. Rajkumar, S., Singh, K.N., Lal, B. and Singh, R.D. (2008). Plant Species Diversity along an Altitudinal Gradient of Bhabha Valley in Western Himalaya. J. Mt. Sci., 5: 157-177.

8. Curtis, J.T. and Mclntosh, R.P. (1950). The interrelations of certain analytic and synthetic phytosociological characters. Ecology, 31(3):434-455.

9. Gairola ,S., Sharma, C.M. , Ghildiyal, S.K. and Suyal, S. (2011). Tree species composition and diversity along an altitudinal gradient in moist tropical montane valley slopes of the Garhwal Himalaya, India. Forest Science and Technology, 7(3): 91-102.

10.Geelani, S.N., Bhat, G.N., Mughal, A.,Husain, M.,Qaiser, Q.N. and Khan, P.A. (2018). Phytosociological status of trees and shrubs of Romshi range of Shopian forest division in Kashmir valley. Journal of Pharmacognosy and Phytochemistry, 7(3): 696-702

11.Jhangir, M. (2004). Phytodiversity characterisation using remote sensing and GIS of district Kathua, Jammu and Kashmir. Ph.D. thesis. University of Jam$\mathrm{mu}$, Jammu, India.

12.Korner, C., (2003). Functional Plant ecology of high mountain ecosystems. Alpine Plant Life, 1-7.

13.Kumar, R. (2012) EIA of Rattle Hydro electric project, Kishtwar, J\&K. Ph. D. Thesis submitted to the University of Jammu.

14.Majila, B.S. and Kala, C.P. (2010). Forest Structure and Regeneration along the Altitudinal Gradient in the Binsar Wildlife Sanctuary, Uttarakhand Himalaya, India. Russian Journal of Ecology, 41(1):75-83.

15.Margalef, D.R.(1958). Information theory in ecology. Genetics and systematic, 3: 36-71.

16.Mark, A.F. (2012). The altitudinal gradient in forest composition, structure and regeneration. New Zealand Journal of Botany. 1(2):188-202.

17.Mishra, A., Sharma, C. M., Sharma, S. D. and Baduni N P. (2000). Effect of aspect on the structure of vegetation community of moist Bhabar and Tarai Shorea robusta forest in Central Himalaya. Indian Forest, 126(6): 634-642.

18.Pala, N.A., Negi, A.K., Gokhale, Y.,Shah, S., and Kumar, M.(2016). Community Structure and Plant Diversity of Community Based Religious Conserved Forests of Garhwal Himalaya, India. Journal of Earth Science \& Climatic Change,7(2): 334.

19.Pande, P.K., Negi, J.D.S.and Sharma,C. (2002). Plant species diversity, composition, gradient analysis and regeneration behaviour of some tree species in a moist temperate Western Himalayan Forest ecosystem. Indian Forester, 8: 869-886.

20.Prakash, R. (1986). Forest management. Dehradun, India: International Book Distributors. p. 214

21.Raina, A.K. and Sharma, N. (2012).Species composition and diversity of tree species along an altitudinal gradient in Sewa catchment of north-western Himalayas, Jammu and Kashmir, India. Environment Conservation Journal,13(1\&2):173-179.

22.Ramsay, P.M. and Oxley, E.R.B. (1997). The growth form composition of plant communities in the Ecuadorian Paramos. Plant Ecology, 131: 173-192.

23.Rawat, R.S. and Pangtey,Y.P.S.(1994). High altitude forests in part of Kumaon, central Himalaya. In: Proceedings of Indian National Sciences Academy, 60 (B):557-564.

24.Rawat, R.S. (2001). Phytosociological studies of 
woody vegetation along an altitudinal gradient in montane forest of Garhwal Himalayas. Indian Journal of Forestry, 24 (4):419-426.

25.Rezende, V.L., Pedro, L. S., Miranda, D., Meyer, L., Moreira, C.V., Mariana, F., Linhares, M. and Filho, AT.O. (2015). Tree species composition and richness along altitudinal gradients as a tool for conservation decisions: the case of Atlantic semideciduous forest. Biodivers. Conserv., 24:2149-2163.

26.Saxena, A.K., Pandey, T. and Singh, J.S. (1985). Altitudinal variation in the vegetation of Kumaon Himalayas. In: D.N. Rao. K.J. Ahmed. M. Yunus \& S.N. Singh (eds.) Perspectives in Environmental Botany. Print House, Lucknow, 43-66.

27.Shannon,C.E. and Weaver, W. (1963). The mathematical theory of communication. University of Illinois Press, Urbana, USA.

28.Sharma, C.M., Suyal, S., Gairola, S. and Ghildiyal, S.K. (2009).Species richness and diversity along an altitudinal gradient in moist temperate forest of Garhwal Himalayas. Journal of American Science ,5 (5):119-128.

29.Sharma, C.M., Mishra, A.K., Tiwari, O.P., Krishan, R. and Rana, Y.S. (2017). Effect of altitudinal gradients on forest structure and composition on ridge tops in Garhwal Himalaya. Energ. Ecol. Environ ,Springer. DOI: 10.1007/s40974-017-0067-6.

30.Sharma, N., and Raina, A.K. (2013). Composition, structure and diversity of tree species along elevational gradient in Jammu province of north-western Himalayas, Jammu and Kashmir. J. Bio.\&Env. Sci.,3 (10):12-23

31.Sharma, N., Najeeb, A. and Singh, D. (2016). Vegetation diversity and distribution along an elevation gradient on both sides of Chattergalla Ridge, Bhaderwah, Jammu and Kashmir, India. Indian Forester, 142(9):820-826

32.Sharma, P., Rana, J. C., Devi, U., Randhawa, S.S. and Kumar, R. (2014). Floristic diversity and distribution pattern of plant communities along altitudinal gradient in Sangla Valley, Northwest Himalaya. Scientific World Journal,1- 11.

33. Shivnath, S., Gupta K. and Rajwar, G.S. (1993). Analysis of forest vegetation in a part of Garhwal Himalaya. Recent Research in Ecology and Environmental Pollution, 6:47-58.

34.Simpson, E.H. (1949). Measurement of diversity. Nature, 163:168.

35.Simpson, G. G.(1964). Species diversity of North American recent mammals. Syst Zool., 13: 52-73

36.Singh, K.N. and Kaushal, R. (2006).Diversity and quantitative analysis of dominant tree species in district Chamba of Himachal Pradesh. Indian Journal of Forestry, 29 (3): 254-251.

37.Singh, S.P., Adhikari, B.S.and Zobel, D.B. (1994). Biomass productivity, leaf longevity and forest structure in the Central Himalaya. Ecologic Monogr,64:401 $-421$

38.Sinha, S. Badola, H.K.,Chhetri, B., Gaira, K.S., Lepcha, J. and Dhyani, P. (2018). Effect of altitude and climate in shaping the forest compositions of Singalila National Park in Khangchendzonga Landscape, Eastern Himalaya, India. Journal of AsiaPacific Biodiversity, 11: 267-275.

39.Song, X., Nakamura, A., Sun,Z., Tang, Y. and Cao, M. (2016). Elevational Distribution of Adult Trees and Seedlings in a Tropical Montane Transect, Southwest China. Mountain Research and Development, 36 (3):342-354.

40.Visalakshi, N.(1995). Vegetation analysis of two tropical dry evergreen forests of southern India. Tropical Ecology, 36:117-127.

41.Whittaker R H. (1965). Dominance and diversity in land plant communities. Science, 147: 250-260.

42.Whittaker, RH.(1977). Evolution of species diversity in plant communities. Evolutionary Biology, 10: 1-67.

43.Wikum, D.A. and Wali, M.K. (1974). Analysis of North Dakota Gallery forest vegetation in relation to topographic and soil gradients. Ecologic. Monogr., 44:441 -464 . 